\title{
CARDIOPULMONARY INTERACTIONS WITH CONSECUTIVE PULMONARY ABNORMALITIES IN PATIENTS WITH CHRONIC HEART FAILURE
}

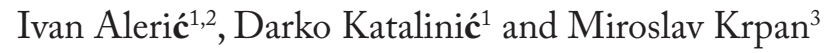 \\ ${ }^{1}$ Department of Internal Medicine, School of Medicine, Josip Juraj Strossmayer University of Osijek, Osijek; \\ ${ }^{2}$ Clinical Department of Pulmonary Medicine, ${ }^{3} \mathrm{Clinical}$ Department of Cardiology, \\ Zagreb University Hospital Centre, Zagreb, Croatia
}

\begin{abstract}
SUMMARY - Chronic heart failure places heavy burden on patients, their families and on health care resources, accounting for high numbers of hospital admissions. Despite huge improvements in the treatment of many heart disorders, the clinical syndrome of chronic heart failure as a final pathway of heart pathology is an exception, in that its prevalence is rising, and only small prolongations in survival are occurring. It is associated with high morbidity and poor prognosis, and a survival rate worse than that for some malignant tumors. The reasons for the increasing overall prevalence of chronic heart failure in developed countries lie in prolonged survival owing to modern pharmacological or invasive treatment, better secondary prevention, and aging of the population. Chronic pulmonary disease is common in patients with chronic heart failure. Through sharing some risk factors and overlapping pathophysiological processes, they present diagnostic and therapeutic challenge. The aim of this article is to review various mechanisms responsible for the symptoms of chronic heart failure with consecutive pulmonary interaction and abnormalities in lung function.
\end{abstract}

Key words: Heart failure; Heart diseases; Lung diseases

\section{Introduction}

Chronic heart failure $(\mathrm{CHF})$ is a clinical syndrome defined by the presence of symptoms, most often as breathlessness and fatigue, and objective clinical signs such as evidence of fluid retention, tachypnea, tachycardia, pleural effusion, pulmonary rales, or ankle swelling. Of course, to establish the diagnosis, these clinical data have to be combined with objective evidence for structural or functional abnormality of the heart. CHF is always a result of the underlying cardiac disease irrespective of whether it involves the myocardium, endocardium with valvar apparatus, or pericardium. The incidence of CHF is reported to be between

Correspondence to: Darko Katalinić, $M D, P h D$, Department of Internal Medicine, School of Medicine, Josip Juraj Strossmayer University of Osijek, Cara Hadrijana 10/E, HR-31000 Osijek, Croatia E-mail: darkodominik@gmail.com

Received February 2, 2017, accepted June 20, 2017
$2.0 \%$ and 5.0 cases per 1000 people per year in western countries, with the increase in the incidence to up to 40 cases per 1000 people per year in the population older than 75 years. The prevalence of this condition is estimated to be around 3\% with a rise in the prevalence to between $3.0 \%$ and $13.0 \%$ in the population older than $65^{1}$. The reasons for the increasing overall prevalence of $\mathrm{CHF}$ in developed countries lie in prolonged survival owing to modern pharmacological or invasive treatment, better secondary prevention, and aging of the population. Thus, overall expenditures are rising with approximately $2 \%$ of national health budgets being spent on the treatment of these patients ${ }^{2}$. The prognosis in $\mathrm{CHF}$ is generally poor. A population based study, Framingham Heart Study, showed the median survival of 3.2 years in men and 5.4 years in women after establishing the diagnosis ${ }^{3}$. Also, mortality as a consequence of $\mathrm{CHF}$ increases with age, showing a $27 \%$ increase in mortality in men with every de- 
cade of life and 61\% increase in women of older age groups ${ }^{4}$. The aim of this article is to review the cardiopulmonary interaction of $\mathrm{CHF}$ with consecutive pulmonary abnormalities. The pathophysiology and treatment of acute heart failure was not considered.

\section{Mechanism and Clinical Impact of Dyspnea in Chronic Heart Failure}

Dyspnea or breathlessness is the most common symptom of $\mathrm{CHF}$, largely due to the lower quality of life in these patients. Clinical follow-up, treatment and prognostication in CHF have been traditionally based on the New York Heart Association Functional Classification (NYHA), which is based on clinical criteria, primarily dyspnea and exercise intolerance. Shortness of breath or dyspnea is a product of a well-defined, complicated interaction between periphery and cortex of the brain. Namely, various receptors contribute to the process. Hypoxia stimulates peripheral and central chemoreceptors: mechanical stimuli activate mechanoreceptors in upper airways of the chest wall, whereas lung comprises pulmonary stretch receptors, which are activated by lung inflation; irritant receptors are activated with chemical stimuli, which promote bronchoconstriction and C-fibers that are placed in the interstitium and react to pulmonary congestion ${ }^{5}$. Breathlessness in CHF is mainly based on the increased breathing effort secondary to changes of lung or chest wall mechanics and respiratory musculature weakness, although a significant role is played by pulmonary congestion and changes in lung function. Many patients in stable condition with no volume overload, unlike subjects with chronic pulmonary diseases, are not hypoxemic. Changes in lung and chest wall mechanics take place due to fluid retention. Left ventricular failure leads to higher end-diastolic ventricular pressure and pulmonary venous hypertension. There is a gradual increase in pulmonary blood flow from the apex to the base of the lung, which can be expected. Elevated pressure makes blood flow uniformly spread and redistributed across the lung. This pulmonary blood flow redistribution is accomplished through capillary recruitment. If the rise of the pulmonary venous pressures continues, fluid would cross the alveolocapillary barrier. This process has been traditionally defined since Starling first described the basic forces regulating fluid migration, with hydrostatic forces favoring the

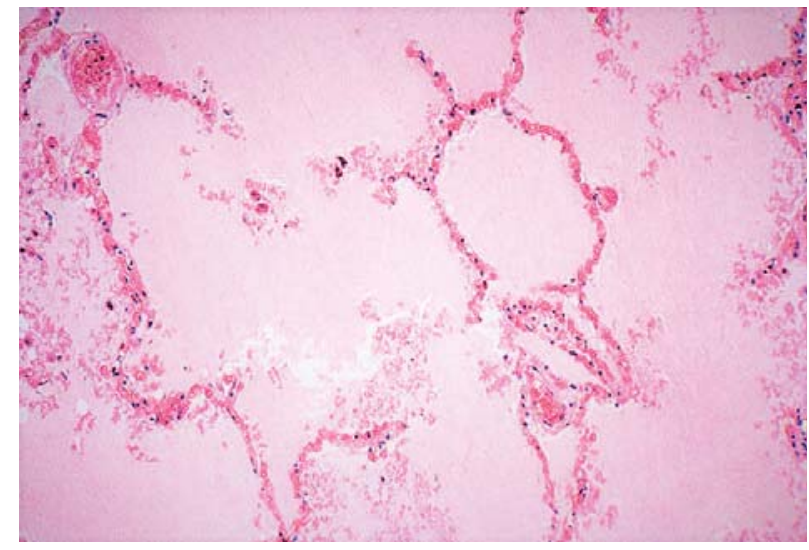

Fig. 1. Histopathologic evaluation of lung edema.

Hematoxylin and eosin histologic analysis shows alveolar walls that are thickened due to distention of capillaries and interstitial edema. Alveolar lumen is filled with transudate and blood (a homogeneous red-pink material) consistent with the diagnosis of lung edema (low-power photomicrograph, original magnification, x100).

crossing of the fluid to alveolar spaces and interstitial oncotic pressures supporting retention of the fluid in the interstitial spaces. Over time, the fluid is being retained in interlobular septa, peribronchovascular interstitium and pleural space with lymphatic system clearing the water overload. Alveolocapillary membrane changes with thickening and fibrosis taking place, which reduces the permeability for fluid. Also, pulmonary veins become thicker and pulmonary arterioles show intimal fibrosis and media thickening. These changes are responsible for relative resistance of the interstitium to high capillary pressures and have been designated as an explanation of how patients with CHF tolerate high pulmonary capillary wedge pressures without experiencing pulmonary edema. Fluid overload in the interstitium, peribronchovascular, hilar and pleural spaces is responsible for lower pulmonary compliance and higher chest stiffness. Because of the long-lasting process of pulmonary venous hypertension in $\mathrm{CHF}$, sometimes damage to alveolocapillary area occurs $^{6}$. Namely, tearing of alveolar epithelium, capillary endothelium and collagen structures of basal membranes takes place and is responsible for extravasation of red blood cells into the alveolar spaces (Fig. 1). This process has been termed pulmonary capillary stress failure. Also, this explains the higher content of hemosiderin in alveolar spaces in patients with long- 
standing chronic heart failure, sometimes leading even to pulmonary ossification. Such changes have been especially well described in patients with long-standing mitral stenosis ${ }^{7}$.

\section{The Role of Respiratory Musculature in Dyspnea and Exercise Intolerance in Patients with Chronic Heart Failure}

Respiratory effort can be simply defined by the sense of 'breathing work' needed to fulfill ventilatory demand in a hypothetical situation. This awareness of effort is a function of the ratio between generated work achieved by respiratory muscles in that hypothetical situation and their maximum capability. Thus, the sense of effort is increased whenever muscles have to generate greater pressure in order to compensate for extra load (such as higher elastic or resistive forces of the lung or chest), or when there is lower pressure generating the capacity of muscles (intrinsic weakness of the respiratory musculature, increase in the chest volume, fatigue of the musculature). A large number of experimental and clinical works have been dedicated to enlighten the role of respiratory musculature in CHF. Most of the work of breathing is done by the diaphragm consisting of 'slow oxidative-fatigue resistant' fibers, which are, on the other hand, very perfusion sensitive. It has been shown that patients with $\mathrm{CHF}$ have a significantly reduced strength of respiratory musculature as compared with healthy individuals of the same age ${ }^{8}$. Moreover, in these patients, muscle strength of other regions in the body has not been reduced in that scale, leading to a conclusion that respiratory muscles depend more on the cardiac output but there are reports suggesting that this disorder is a general one, with respiratory muscles to be affected earli$\mathrm{er}^{9}$. McParland et al. proved that respiratory muscle strength was reduced in patients with $\mathrm{CHF}$, and what is more, that this reduction of respiratory muscle strength correlated with dyspnea on performing everyday activities ${ }^{10}$.

In another study, McParland et al. confirmed these findings and found no connection of muscle weakness with nutritional or electrolyte status in patients with $\mathrm{CHF}^{11}$. Mancini et al. demonstrated hypoxia to take place in respiratory muscles during exercise in patients with CHF; in a subsequent study, Mancini et al. showed not only linear connection between respi- ratory muscle strength and dyspnea, but also changes of diaphragm workload and lack of muscle fatigue during exercise in patients with cardiac failure ${ }^{12,13}$. In another study by Evans et al., weakness of respiratory muscles in CHF was found again, but without correlation with dyspnea or exercise intolerance ${ }^{14}$. Respiratory muscle endurance defined as the ability of the muscle to resist fatigue is a sign of respiratory musculature dysfunction, which is depressed in $\mathrm{CHF}$ patients and tends to correlate with their exercise intolerance ${ }^{15,16}$. Relative inconclusiveness of various studies regarding the connection between respiratory muscle dysfunction and dyspnea or exercise intolerance may be a consequence of different methodology, small number of patients, or variability of patient characteristics. Nevertheless, rehabilitation and training of inspiratory muscles in patients with $\mathrm{CHF}$ showed clear benefit ${ }^{17-19}$.

\section{Lung Function in Chronic Heart Failure}

Changes in lung functions in patients with $\mathrm{CHF}$ have been well studied. As regards the fact that dyspnea is the most frequent of all symptoms in these patients, great interest was directed towards understanding of the underlying process. Respective studies used pulmonary function testing and showed that patients with CHF predominantly had a restrictive pattern of breathing. There are several reasons that can explain such findings. Firstly, these patients exhibit volume overload with liquid retention in pulmonary interstitial, alveolar and pleural spaces. Secondly, the size of the heart is enlarged. Agostoni et al. conducted a study in which cardiothoracic index on conventional chest $\mathrm{x}$-ray correlated inversely with the parameters of lung function ${ }^{20}$. Thirdly, stiffness of the lung due to water retention contributes as well. Bearing the fact of unique thoracic space in mind, which comprises heart, lungs and other structures in a given volume, these changes are directly reducing the useful lung volume. Indeed, the relation between cardiomegaly and deterioration of lung function was directly studied showing positive correlation ${ }^{20}$. Lung function testing in CHF predominantly shows reduced total lung capacity (TLC) and forced vital capacity (FVC) ${ }^{21-23}$. Consequently, the ratio between forced expiratory volume in first second (FEV1) and FVC is increased. Also, residual volume tends to be increased with reduction of 
vital capacity. Namely, accumulation of retained liquid in peribronchovascular spaces leads to erection of distended vessels and compression of bronchioles with air trapping ${ }^{24}$. After intensive diuretic treatment or heart transplantation, all of these changes tend to be corrected $^{25-27}$. Acute heart failure shows completely different lung function disturbance patterns with predominantly obstructive changes in lung function testing ${ }^{28,29}$. This explains wheezing in clinical presentation of such patients. The reason for this lies in airway obstruction due to wall congestion of smaller airways. All of these changes have also been shown to improve following diuretic therapy, although it is interesting that bronchodilator therapy did not improve airway obstruction $^{28}$. Finally, bronchial hyperreactivity in CHF may play a significant role. This can be explained by congestion and thickening of the bronchial mucosa layer with activation of irritant receptors and C-fibers. Vagotomy in experimental animals put in the setting of cardiac failure has shown betterment of lung function ${ }^{30}$. Indeed, patients with CHF were shown to have significantly higher bronchial hyperreactivity with acetylcholine inhalation testing ${ }^{31}$. Lung function during physical activity in patients with CHF shows striking change with regard to the pathologic pattern of ventilation in which patients produce higher respiratory rate with low tidal volume, in contrast to healthy subjects where physical demand is met with the increase in both tidal volume and respiratory frequency, yielding a higher ventilation rate in patients with congestive $\mathrm{CHF}$ for a given workload. There are several explanations, most important being changes in lung mechanics with the increase in the overall chest volume and stiffness, lower lung compliance, all of which make respiratory muscles ineffective, weak and prone to fatigue. Moreover, lung diffusion is reduced and dead space ventilation is increased ${ }^{23}$. This hyperventilating pattern correlates with the rate of dyspnea and physical exercise intolerance ${ }^{32,33}$. Also, the severity and prognosis of $\mathrm{CHF}$ can be estimated with low ventilatory efficiency defined as high ventilation drive relative to the given carbondioxide production ${ }^{34-36}$.

\section{Lung Diffusion in Chronic Heart Failure}

Gas diffusion takes place at the alveolocapillary membrane which, in a simplified model, consists of alveolar epithelium, capillary endothelium, and their basal membranes. Electron microscopy has shown that this membrane is not uniformly structured but is composed of a thinner and thicker part with regard to the interstitial matrix content. On the thinner side, capillary endothelium and alveolar epithelium are closely positioned with tight junctions and basal membranes fused, whereas on the thicker side these structures are mediated by the protein-rich interstitium ${ }^{37}$. Thin part of the membrane is designed to optimally fulfill the task of gas diffusion, and the thick part, in the setting of higher hydrostatic pressures (as in CHF), takes over the fluid and removes it from the critical area where gas diffusion takes place. Generally, diffusing capacity of the lung for carbon monoxide (DLCO) is a function of membrane conductance on the one hand, and of the blood volume in the capillaries with the rate of hemoglobin on the other hand. Patients with $\mathrm{CHF}$ were shown to have reduced DLCO with linear deterioration of lung diffusion in patients with more severe $\mathrm{CHF}^{38-40}$. The reason for reduced DLCO presumably lies in chronic changes of the alveolocapillary membrane with fluid accumulation, fibrosis, and subsequent reduction of membrane conductance. Also, this reduction is obviously not compensated enough with larger volume of capillary blood flow as would be expected giving the fact of pulmonary venous hypertension in these patients. Also, these changes are not completely reversible because patients after heart transplantation keep approximately the same DLCO as before the operation ${ }^{41,42}$. After heart transplantation, DLCO tends to decline at first, which probably resembles the decline in capillary blood flow due to reduction in pulmonary venous pressure ${ }^{43-45}$. All these changes show that DLCO reduction in patients with CHF does not depend solely on fluid retention but rather is a longlasting process with formation of chronic changes to alveolocapillary membrane, or may be a consequence of accompanying pulmonary disease. This conclusion is supported by the fact that ultrafiltration in patients with CHF improves lung volumes and mechanical properties of the lung but is unable to improve DLCO, which means that this parameter is not completely fluid-dependent $t^{46}$. Impaired lung diffusion was shown to be related to depressed exercise capacity in patients with heart failure ${ }^{47-49}$. Also, membrane conductance, of all respiratory function parameters, correlated best with exercise ventilation efficiency and prognosis in patients with heart failure ${ }^{50,51}$. Exercise training in pa- 
tients with heart failure can improve DLCO and exercise performance ${ }^{52}$.

\section{Ventilation-Perfusion Mismatch in Chronic Heart Failure}

As mentioned above, redistribution of pulmonary capillary perfusion takes place in patients with cardiac failure due to pulmonary venous hypertension and volume overload. Changes of lung volumes and mechanics also occur. This makes patients with $\mathrm{CHF}$ more prone to ventilation-perfusion mismatching. In normal conditions, there is no alveolar dead space but, rather, dead space is a consequence of anatomic dead space. It has been shown that exercise ventilation pattern in $\mathrm{CHF}$ is a pathologic one with hyperventilation and low efficiency. The reason, among others mentioned earlier, lies in the inability of the lung to augment tidal volume during exercise, which makes breathing in these conditions shallow and rapid. Also, the ratio between the dead space volume and tidal volume stays constant in exercise, suggesting that there are areas of high ventilation-perfusion mismatch with under perfused alveolar spaces, probably due to low cardiac output ${ }^{53}$. These facts when summarized bring us to a conclusion that there is a connection between low efficient breathing, exercise intolerance and ventilation-perfusion mismatch with high respiratory drive to compensate for the under perfused areas of the lung ${ }^{54}$.

\section{Sleep Disordered Breathing in Chronic Heart Failure}

Chronic heart failure is tightly connected with sleep-disordered breathing (SDB). SDB can be divided into obstructive sleep apnea/hypopnea (OSA), which is defined as five or more apnea/hypopnea episodes per hour (apnea/hypopnea index, AHI) that occur due to obstruction of upper airways, combined with extreme respiratory effort and central sleep apnea (CSA), which is defined the same as OSA but without traceable respiratory effort during apnea/hypopnea episodes $^{55-60}$. Both OSA and CSA can coexist in some patients. CSA can be accompanied with CheyneStokes respiration, periodic breathing where apneas alternate with rapidly emerging and waning ventilation. Among patients with $\mathrm{CHF}, 50 \%$ of them suffer from SDB, with $80 \%$ of them having CSA and the rest having $\mathrm{OSA}^{61}$. OSA/CSA result in repetitive oxyhemoglobin desaturations with consequential arousals, activation of sympathetic system, and increase in arterial blood pressure. OSA is thought to be a major causal factor for cardiovascular diseases and CHF, firstly through its clear effect on the incidence of arterial hypertension as a major cardiovascular risk factor, then through mechanical and hemodynamic effects of negative intrathoracic pressures; OSA has also been associated with activation of the sympathetic nervous system, endothelial dysfunction and systemic inflamma$\operatorname{tion}^{62-67}$. CSA with or without Cheyne-Stokes respiration pattern is a consequence of CHF. This form of SDB occurs due to instability of the respiratory system in patients with $\mathrm{CHF}^{68-69}$. Respiration during sleep is controlled by the interaction between brainstem centers, respiratory apparatus (inspiratory musculature, pulmonary parenchyma) and chemoreceptors. Tight correlation between the ventilatory cycle duration and left ventricular ejection fraction has led to a conclusion that low cardiac output and timely transport of the chemostimuli to the chemoreceptors are responsible for the prolonged ventilatory cycle in $\mathrm{CHF}$ patients ${ }^{70}$. Thus, chemoreceptors produce an exaggerated answer to low partial pressures of carbon dioxide, finally leading to apnea or hypopnea. Low partial pressure of carbon dioxide is, on the other hand, a consequence of hyperventilation or high respiratory drive in CHF. It is believed that partial pressure of carbon dioxide is the most important indicator of respiratory drive control, as confirmed by a study with reversal of CSA with carbon dioxide inhalation ${ }^{71}$. CSA can worsen the existing $\mathrm{CHF}$ through its effect on further activation of the sympathetic system, hypoxemia, blood pressure variations, and cardiac arrhythmia, and also worsens the prognosis with increase of mortality in patients with higher $\mathrm{AHI}^{72}$. Sleep breathing disorders in CHF can be improved with treatment. OSA has been successfully treated with continuous positive airway pressure $^{68}$. Studies with optimization of chronic pharmacotherapy have shown success in treating CSA in patients with CHF; supplementing oxygen via nasal cannula has also been shown effective $\mathrm{e}^{74,75}$. The administration of bronchodilation agents showed beneficial effect on SDB and acetazolamide-mild diuretic given before sleep produces mild metabolic acidosis, therefore decreases partial pressure of carbon dioxide and resets the apnea/hypopnea threshold resulting in fewer 
episodes of apnea, better oxyhemoglobin saturation, and improving the quality of sleep ${ }^{76,77}$. Noninvasive continuous positive airway pressure treatment reduces sympathetic system activation, arrhythmia incidence, arterial hypertension, and improves left ventricular ejection fraction and volume ${ }^{78,79}$. There is no clear effect on mortality reduction ${ }^{80}$.

\section{Radiographic Manifestation of Chronic Heart Failure}

Chronic heart failure with pulmonary venous hypertension and volume overload brings along characteristic radio-morphological changes in thoracic imaging. Conventional chest radiogram has been traditionally considered to be the most appropriate tool for diagnosis and follow-up of CHF. Normally, pulmonary blood flow has its characteristic distribution pattern with better perfused area of the lung being its basal part and less perfused area of the lung being the apex, accordingly with gravitational force. Pulmonary blood flow is a low-pressure and low-resistance system with large capacity for accommodation in case of pulmonary venous hypertension and volume overload. Rise in left ventricular end-diastolic pressure, which can be approximated with the rise in pulmonary capillary wedge pressure, in patients with $\mathrm{CHF}$ leads to changes in pulmonary blood flow. Capillaries in the apical parts of the lung, previously collapsed, are being recruited and those in the base of the lung are being distended. This change in physiological perfusion of the lung is called redistribution of the pulmonary blood flow. Logically, pulmonary artery-to-bronchus diameter ratio changes as well. Namely, with volume overload arteries gain greater diameter and surpass diameter of the accompanying bronchus, especially in lower parts of the lung ${ }^{81}$. Cardiomegaly is another typical radiographic sign of congestive $\mathrm{CHF}$, although not especially sensitive or specific. It has sensitivity of 50\% and specificity of around 75\%. Cardiomegaly is best appreciated through cardiothoracic ratio. This ratio is calculated by dividing transverse cardiac diameter with transverse chest diameter measured on chest $\mathrm{x}$-ray, and cardiomegaly is present when the ratio surpasses $50 \%$. Another feature of the heart silhouette on chest x-ray, vascular pedicle, which comprises great intrathoracic vessels, widens on chest $\mathrm{x}$-ray. This pedicle is routinely measured as a field that is limited on the right with
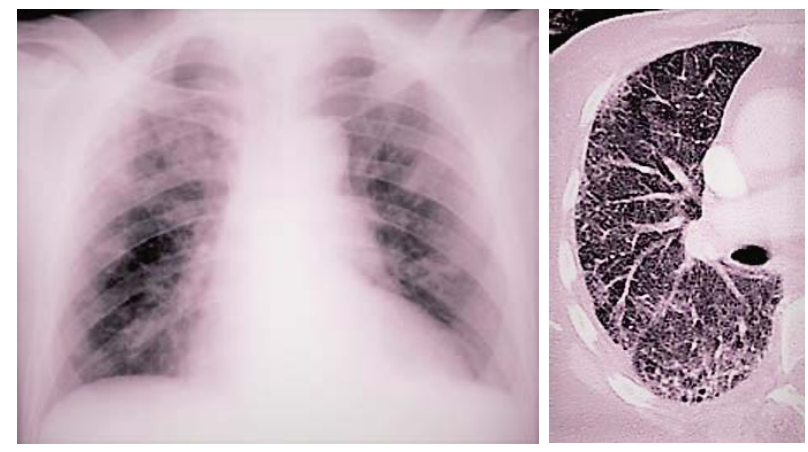

Fig. 2. Radiological evaluation of chronic heart failure.

Chest radiograph of a 65-year-old man with chronic cough and dilatative cardiomyopathy shows interstitial abnormalities. Kerley B lines are notably present in both lung lobes. Cardiomegaly and distension of the right upper lobe and the right lower lobe veins suggest the diagnosis of chronic heart failure (right panel). High-resolution computed tomography scan of the chest reveals pulmonary edema (left panel).

superior vena cava and on the left with the point of the subclavian artery take-off. Normally, this diameter is 6.0 centimeters or less and is considered pathological when 8.5 centimeters or greater. The azygos vein seen on the chest $\mathrm{x}$-ray when dilated is a sign of increased right atrial pressure. Normal diameter of the vein is about 7.0 millimeters and when the diameter is 10.0 or more millimeters, it should be considered abnormal and suggests volume overload. As pulmonary venous pressure keeps rising, interstitial edema is formed ${ }^{82,83}$. It is a consequence of fluid leakage into the interlobular and peribronchial interstitium. When the fluid leaks into peripheral interlobular interstitium, it can be appreciated as Kerley B lines on chest $\mathrm{x}$-ray. These are peripherally mounted small horizontal lines that run perpendicularly to the pleura. Edema of the peribronchial interstitium presents as bronchial wall thickening. If pulmonary venous pressure would increase further, alveolar edema and flooding of alveolar spaces would take place. Computerized tomography of the chest is not a method of choice for screening or follow-up of patients with CHF for being expensive, relatively inaccessible, and associated with high radiation dose, although patients with CHF demonstrate typical findings such as interstitial edema with thickened septal lines and ground glass opacities in dependent part of the lung ${ }^{82-84}$ (Fig. 2). 


\section{Conclusion}

Evaluation of cardiac and pulmonary function and interactions between $\mathrm{CHF}$ and consequential chronic lung disease is complex and incompletely understood, often problematic and occasionally misleading. Both conditions are systemic disorders with overlapping pathophysiological processes, and they present diagnostic and therapeutic challenge. Pulmonary function is frequently abnormal, with a decrease in vital capacity shown to precede clinical recognition of $\mathrm{CHF}$. DLCO is often mildly reduced and does not normalize following heart transplantation. Reduced lung compliance, increased dead space ventilation, and muscle weakness contribute to the preceding abnormalities in producing exercise limitation. Sleep apnea, particularly of the central variety, is associated with chronic $\mathrm{CHF}$ and confers worse prognosis. Various limitations of clinical evaluation may lead to difficulties in the diagnosis, and consequently in the treatment of CHF, particularly when the presentation is atypical or when lung disease already exists. The resulting symptomatic and prognostic benefits outweigh those attainable by treating either condition alone. Additional studies providing new data on the pathogenesis and management of patients with CHF are needed, with the purpose of trying to improve the quality of life, appropriate treatment, as well as survival of these patients. While many of these therapies will improve the care of patients with $\mathrm{CHF}$, significant reductions in the prevalence will require vigorous, multifaceted, preventive approaches. Only through high appreciation of the complex interactions between the heart and the lung, diagnostic and treatment-related errors can be minimized. A high degree of cooperation is ultimately required among cardiologists, pulmonologists and radiologists in order to better identify and manage these clinical entities. All clinicians attending these patients should perform an integrated approach to objectively identify both diseases at an early stage, and to optimize control of respiratory and cardiovascular conditions.

\section{References}

1. Cowie MR, Mosterd A, Wood DA. The epidemiology of heart failure. Eur Heart J. 1997;18:208-25. doi:10.1093/oxfordjournals.eurheartj.a015223
2. Stewart S, Jenkins A, Buchan S, McGuire A, Capewell S, McMurray JJ. The current cost of heart failure to the National Health Service in the UK. Eur J Heart Fail. 2002;4:361-71. doi:10.1016/S1388-9842(01)00198-2

3. Ho KK, Anderson KM, Kannel WB, Grossman W, Levy D. Survival after the onset of congestive heart failure in Framingham Heart Study subjects. Circulation. 1993;88(1):107-15. doi:10.1161/01.CIR.88.1.107

4. Ho KK, Pinsky JL, Kannel WB. The epidemiology of heart failure: the Framingham Study. J Am Coll Cardiol. 1993;22: 6A-13A. doi:10.1016/0735-1097(93)90455-A

5. Manning HL, Mahler DA. Pathophysiology of dyspnea. Monaldi Arch Chest Dis. 2001;56(4):325-30.

6. West JB, Mathieu-Costello O. Vulnerability of pulmonary capillaries in heart disease. Circulation. 1995;92:622-31. doi:10.1161/01.CIR.92.3.622

7. Kay JM, Edwards FR. Ultrastructure of the alveolar-capillary wall in mitral stenosis. J Pathol. 1973;111:239-45. doi:10.1002/ path.1711110404

8. Hammond MD, Bauer KA, Sharp JT, Rocha RD. Respiratory muscle strength in congestive heart failure. Chest. 1990; 98(5):1091-4. doi:10.1378/chest.98.5.1091

9. Chua TP, Anker SD, Harrington D, Coats AJ. Inspiratory muscle strength is a determinant of maximum oxygen consumption in chronic heart failure. Br Heart J. 1995;74(4): 381-5. doi:10.1136/hrt.74.4.381

10. McParland C, Krishnan B, Wang Y, Gallagher CG. Inspiratory muscle weakness and dyspnea in chronic heart failure. Am Rev Respir Dis. 1992;146(2):467-72. doi:10.1164/ajrccm/146.2.467

11. McParland C, Resch F, Krishnan B, Wang Y, Cujec B, Gallagher C. Inspiratory muscle weakness in chronic heart failure: role of nutrition and electrolyte status and systemic myopathy. Am J Respir Crit Care Med. 1995;151:1101-7. doi:10.1164/ ajrccm/151.4.1101

12. Mancini DM, Ferraro N, Nazzaro D, Chance B, Wilson JR. Respiratory muscle deoxygenation during exercise in patients with heart failure demonstrated with near-infrared spectroscopy. J Am Coll Cardiol. 1991;18:492-8. doi:10.1016/07351097(91)90605-9

13. Mancini DM, Walter G, Reichek N, Lenkinski R, McCully KK, Mullen JL, et al. Contribution of skeletal muscle atrophy to exercise intolerance and altered muscle metabolism in heart failure. Circulation. 1992;85:1364-73. doi:10.1161/01.CIR.85.4.1364

14. Evans SA, Watson L, Cowley AJ, Johnston ID, Kinnear WJ. Static lung compliance in chronic heart failure: relation with dyspnoea and exercise capacity. Thorax. 1995;50(3):245-8. doi:10.1136/thx.50.3.245

15. Walsh JT, Andrews R, Johnson P, Phillips L, Cowley AJ, Kinnear WJ. Inspiratory muscle endurance in patients with chronic heart failure. Heart. 1996;76(4):332-6. doi:10.1136/ hrt.76.4.332

16. Mancini DM, Henson D, LaManca J, Levine S. Evidence of reduced respiratory muscle endurance in patients with heart failure. J Am Coll Cardiol. 1994;24(4):972-81. doi:10.1016/0735-1097(94)90858-3 
17. Mancini DM, Henson D, La Manca J, Donchez L, Levine S. Benefit of selective respiratory muscle training on exercise capacity in patients with chronic congestive heart failure. Circulation. 1995;91(2):320-9. doi:10.1161/01.CIR.91.2.320

18. Laoutaris I, Dritsas A, Brown MD, Manginas A, Alivizatos $\mathrm{PA}$, Cokkinos DV. Inspiratory muscle training using an incremental endurance test alleviates dyspnea and improves functional status in patients with chronic heart failure. Eur J Cardiovasc Prev Rehabil. 2004;11(6):489-96. doi:10.1097/01.hjr.0000152242.51327.63

19. Dall'Ago P, Chiappa GR, Guths H, Stein R, Ribeiro JP. Inspiratory muscle training in patients with heart failure and inspiratory muscle weakness: a randomized trial.J Am Coll Cardiol. 2006;47(4):757-63. doi:10.1016/j.jacc.2005.09.052

20. Agostoni P, Cattadori G, Guazzi M, Palermo P, Bussotti M, Marenzi G. Cardiomegaly as a possible cause of lung dysfunction in patients with heart failure. Am Heart J. 2000;140(5):e24. doi:10.1067/mhj.2000.110282

21. Wright RS, Levine MS, Bellamy PE, Simmons MS, Batra P, Stevenson LW, et al. Ventilatory and diffusion abnormalities in potential heart transplant recipients. Chest. 1990;98(4):816-20. doi:10.1378/chest.98.4.816

22. Naum CC, Sciurba FC, Rogers RM. Pulmonary function abnormalities in chronic severe cardiomyopathy preceding cardiac transplantation. Am Rev Respir Dis. 1992;145(6):1334-8. doi:10.1164/ajrccm/145.6.1334

23. Agostoni P, Cattadori G, Bussotti M, Apostolo A. Cardiopulmonary interaction in heart failure. Pulm Pharmacol Ther. 2007;20(2):130-4. doi:10.1016/j.pupt.2006.03.001

24. Ishii M, Matsumoto N, Fuyuki T, Hida W, Ichinose M, Inoue $\mathrm{H}$, et al. Effects of hemodynamic edema formation on peripheral vs. central airway mechanics. J Appl Physiol. 1985;59 (5):1578-84.

25. Hosenpud JD, Stibolt TA, Atwal K, Shelley D. Abnormal pulmonary function specifically related to congestive heart failure: comparison of patients before and after cardiac transplantation. Am J Med. 1990;88(5):493-6. doi:10.1016/0002-9343(90)90428-G

26. Ravenscraft SA, Gross CR, Kubo SH, Olivari MT, Shumway SJ, Bolman RM $3^{\text {rd }}$, et al. Pulmonary function after successful heart transplantation. One year follow-up. Chest. 1993;103 (1):54-8.

27. Faggiano P, Lombardi C, Sorgato A, Ghizzoni G, Spedini C, Rusconi C. Pulmonary function tests in patients with congestive heart failure: effects of medical therapy. Cardiology. 1993;83(1-2):30-5. doi:10.1159/000175944

28. Light RW, George RB. Serial pulmonary function in patients with acute heart failure. Arch Intern Med. 1983;143(3):429-33. doi:10.1001/archinte.1983.00350030039007

29. Petermann W, Barth J, Entzian P. Heart failure and airway obstruction. Int J Cardiol. 1987;17(2):207-9. doi:10.1016/0167-5273(87)90132-X

30. Lloyd TC Jr, Cooper JA. Failure of tracheal distension to inhibit breathing in anesthetized dogs. J Appl Physiol. 1980; 48(5):794-8.
31. Brunnée T, Graf K, Kastens B, Fleck E, Kunkel G. Bronchial hyperreactivity in patients with moderate pulmonary circulation overload. Chest. 1993;103(5):1477-81. doi:10.1378/chest.103.5.1477

32. Sullivan MJ, Higginbotham MB, Cobb FR. Increased exercise ventilation in patients with chronic heart failure: intact ventilatory control despite hemodynamic and pulmonary abnormalities. Circulation. 1988;77(3):552-9. doi:10.1161/01.CIR.77.3.552

33. Myers J, Salleh A, Buchanan N, Smith D, Neutel J, Bowes E, et al. Ventilatory mechanisms of exercise intolerance in chronic heart failure. Am Heart J. 1992;124(3):710-9. doi:10.1016/0002-8703(92)90282-Z

34. Kleber FX, Vietzke G, Wernecke KD, Bauer U, Opitz C, Wensel $\mathrm{R}$, et al. Impairment of ventilatory efficiency in heart failure: prognostic impact. Circulation. 2000;101(24):2803-9. doi:10.1161/01.CIR.101.24.2803

35. Jankowska EA, Witkowski T, Ponikowska B, Reczuch K, Borodulin-Nadzieja L, Anker SD, et al. Excessive ventilation during early phase of exercise: a new predictor of poor long-term outcome in patients with chronic heart failure. Eur J Heart Fail. 2007;9(10):1024-31. doi:10.1016/j.ejheart.2007.07.001

36. Arena R, Myers J,Hsu L, Peberdy MA, Pinkstaff S, Bensimhon $\mathrm{D}$, et al. The minute ventilation/carbon dioxide production slope is prognostically superior to the oxygen uptake efficiency slope. J Card Fail. 2007;13(6):462-9. doi:10.1016/j.cardfail.2007.03.004

37. Gehlbach BK, Geppert E. The pulmonary manifestations of left heart failure. Chest. 2004;125(2):669-82. doi:10.1378/chest.125.2.669

38. Guazzi M. Alveolar gas diffusion abnormalities in heart failure. J Card Fail. 2008;14(8):695-702. doi:10.1016/j.cardfail.2008.06.004

39. Guazzi M. Alveolar-capillary membrane dysfunction in heart failure: evidence of a pathophysiologic role. Chest. 2003;124 (3):1090-102. doi:10.1378/chest.124.3.1090

40. Agostoni P, Bussotti M, Cattadori G, Margutti E, Contini M, Muratori M, et al. Gas diffusion and alveolar-capillary unit in chronic heart failure. Eur Heart J. 2006;27(21):2538-43. doi:10.1093/eurheartj/eh1302

41. Bussières LM, Pflugfelder PW, Ahmad D, Taylor AW, Kostuk WJ. Evolution of resting lung function in the first year after cardiac transplantation. Eur Respir J. 1995;8(6):959-62.

42. Niset G, Ninane V, Antoine M, Yernault JC. Respiratory dysfunction in congestive heart failure: correction after heart transplantation. Eur Respir J. 1993;6(8):1197-201.

43. Ulrik CS, Carlsen J, Arendrup H, Aldershvile J. Pulmonary function in chronic heart failure. Changes after heart transplantation. Scand Cardiovasc J. 1999;33(3):131-6.

44. Ewert R, Wensel R, Bettmann M, Spiegelsberger S, Grauhan $\mathrm{O}$, Hummel $\mathrm{M}$, et al. Ventilatory and diffusion abnormalities in long-term survivors after orthotopic heart transplantation. Chest. 1999;115(5):1305-11. doi:10.1378/chest.115.5.1305 
45. Mettauer B, Lampert E, Charloux A, Zhao QM, Epailly E, Oswald M, et al. Lung membrane diffusing capacity, heart failure, and heart transplantation. Am J Cardiol. 1999;83(1):62-7. doi:10.1016/S0002-9149(98)00784-X

46. Agostoni PG, Guazzi M, Bussotti M, Grazi M, Palermo P, Marenzi G. Lack of improvement of lung diffusing capacity following fluid withdrawal by ultrafiltration in chronic heart failure. J Am Coll Cardiol. 2000;36(5):1600-4. doi:10.1016/S0735-1097(00)00929-3

47. Agostoni PG, Bussotti M, Palermo P, Guazzi M. Does lung diffusion impairment affect exercise capacity in patients with heart failure? Heart. 2002;88(5):453-9. doi:10.1136/heart.88.5.453

48. Smith AA, Cowburn PJ, Parker ME, Denvir M, Puri S, Patel $\mathrm{KR}$, et al. Impaired pulmonary diffusion during exercise in patients with chronic heart failure. Circulation. 199928;100 (13):1406-10. doi:10.1161/01.CIR.100.13.1406

49. Puri S, Baker BL, Dutka DP, Oakley CM, Hughes JM, Cleland JG. Reduced alveolar-capillary membrane diffusing capacity in chronic heart failure. Its pathophysiological relevance and relationship to exercise performance. Circulation. 1995;91(11): 2769-74. doi:10.1161/01.CIR.91.11.2769

50. Guazzi M, Reina G, Tumminello G, Guazzi MD. Alveolarcapillary membrane conductance is the best pulmonary function correlate of exercise ventilation efficiency in heart failure patients. Eur J Heart Fail. 2005;7(6):1017-22. doi:10.1016/j.ejheart.2004.10.009

51. Guazzi M, Pontone G, Brambilla R, Agostoni P, Reina G. Alveolar-capillary membrane gas conductance: a novel prognostic indicator in chronic heart failure. Eur Heart J. 2002;23(6): 467-76. doi:10.1053/euhj.2001.2803

52. Guazzi M, Reina G, Tumminello G, Guazzi MD. Improvement of alveolar-capillary membrane diffusing capacity with exercise training in chronic heart failure. J Appl Physiol. 2004;97(5):1866-73. doi:10.1152/japplphysiol.00365.2004

53. Wada O, Asanoi H, Miyagi K, Ishizaka S, Kameyama T, Seto $\mathrm{H}$, et al. Importance of abnormal lung perfusion in excessive exercise ventilation in chronic heart failure. Am Heart J. 1993;125(3):790-8. doi:10.1016/0002-8703(93)90173-7

54. Sullivan MJ, Higginbotham MB, Cobb FR. Increased exercise ventilation in patients with chronic heart failure: intact ventilatory control despite hemodynamic and pulmonary abnormalities. Circulation. 1988;77(3):552-9. doi:10.1161/01.CIR.77.3.552

55. The Report of an American Academy of Sleep Medicine Task Force. Sleep-related breathing disorders in adults: recommendations for syndrome definition and measurement techniques in clinical research. Sleep. 1999;22(5):667-89.

56. Thurnheer R, Ulrich S, Bloch KE. Precapillary pulmonary hypertension and sleep-disordered breathing: is there a link? Respiration. 2017;93(1):65-77. doi:10.1159/000452957

57. Sands SA, Owens RL. Congestive heart failure and central sleep apnea. Sleep Med Clin. 2016;11(1):127-42. doi:10.1159/000452957
58. Naughton MT. Heart failure and sleep-disordered breathing. The chicken or the egg? Am J Respir Crit Care Med. 2016 Mar 1;193(5):482-3. doi:10.1164/rccm.201511-2176ED

59. Arzt M, Woehrle H, Oldenburg O, Graml A, Suling A, Erdmann E, et al. Prevalence and predictors of sleep-disordered breathing in patients with stable chronic heart failure: The SchlaHF Registry. JACC Heart Fail. 2016 Feb;4(2):116-25. doi:10.1016/j.jchf.2015.09.014

60. Magalang UJ, Pack AI. Heart failure and sleep-disordered breathing - the plot thickens. N Engl J Med. 2015 Sep 17; 373(12):1166-7. doi:10.1056/NEJMe1510397

61. Javaheri S, Parker TJ, Liming JD, Corbett WS, Nishiyama H, Wexler L, et al. Sleep apnea in 81 ambulatory male patients with stable heart failure. Types and their prevalences, consequences, and presentations. Circulation. 1998;97(21):2154-9. doi:10.1161/01.CIR.97.21.2154

62. Quan SF, Gersh BJ, National Center on Sleep Disorders Research, National Heart, Lung, and Blood Institute. Cardiovascular consequences of sleep-disordered breathing: past, present and future: report of a workshop from the National Center on Sleep Disorders Research and the National Heart, Lung, and Blood Institute. Circulation. 2004;109(8):951-7. doi:10.1161/01.CIR.0000118216.84358.22

63. Peppard PE, Young T, Palta M, Skatrud J. Prospective study of the association between sleep-disordered breathing and hypertension. N Engl J Med. 2000;342(19):1378-84. doi:10.1056/NEJM200005113421901

64. Nieto FJ, Young TB, Lind BK, Shahar E, Samet JM, Redline S, et al. Association of sleep-disordered breathing, sleep apnea, and hypertension in a large community-based study. Sleep Heart Health Study. JAMA. 2000;283(14):1829-36. doi:10.1001/jama.283.14.1829

65. Ziegler MG, Mills PJ, Loredo JS, Ancoli-Israel S, Dimsdale JE. Effect of continuous positive airway pressure and placebo treatment on sympathetic nervous activity in patients with obstructive sleep apnea. Chest. 2001;120(3):887-93.

doi:10.1378/chest.120.3.887

66. Vgontzas AN, Chrousos GP. Sleep, the hypothalamic-pituitary-adrenal axis, and cytokines: multiple interactions and disturbances in sleep disorders. Endocrinol Metab Clin North Am. 2002;31(1):15-36. doi:10.1016/S0889-8529(01)00005-6

67. Shamsuzzaman AS, Winnicki M, Lanfranchi P, Wolk R, Kara $\mathrm{T}$, Accurso V, et al. Elevated C-reactive protein in patients with obstructive sleep apnea. Circulation. 2002;105(21):2462-4. doi:10.1161/01.CIR.0000018948.95175.03

68. Naughton MT, Lorenzi-Filho G. Sleep in heart failure. Prog Cardiovasc Dis. 2009;51(4):339-49. doi:10.1016/j.pcad.2008.02.001

69. Garcia-Touchard A, Somers VK, Olson LJ, Caples SM. Central sleep apnea: implications for congestive heart failure. Chest. 2008;133(6):1495-504. doi:10.1378/chest.07-0871

70. Hall MJ, Xie A, Rutherford R, Ando S, Floras JS, Bradley TD. Cycle length of periodic breathing in patients with and without 
heart failure. Am J Respir Crit Care Med. 1996;154(2 Pt 1): 376-81. doi:10.1164/ajrccm.154.2.8756809

71. Lorenzi-Filho G, Rankin F, Bies I, Douglas Bradley T. Effects of inhaled carbon dioxide and oxygen on Cheyne-Stokes respiration in patients with heart failure. Am J Respir Crit Care Med. 1999;159(5 Pt 1):1490-8.

doi:10.1164/ajrccm.159.5.9810040

72. Lanfranchi PA, Braghiroli A, Bosimini E, Mazzuero G, Colombo R, Donner CF, et al. Prognostic value of nocturnal Cheyne-Stokes respiration in chronic heart failure. Circulation. 1999;99(11):1435-40. doi:10.1161/01.CIR.99.11.1435

73. Mansfield DR, Gollogly NC, Kaye DM, Richardson M, Bergin P, Naughton MT. Controlled trial of continuous positive airway pressure in obstructive sleep apnea and heart failure. Am J Respir Crit Care Med. 2004;169(3):361-6. doi:10.1164/rccm.200306-752OC

74. Dark DS, Pingleton SK, Kerby GR, Crabb JE, Gollub SB, Glatter TR, et al. Breathing pattern abnormalities and arterial oxygen desaturation during sleep in the congestive heart failure syndrome. Improvement following medical therapy. Chest. 1987;91(6):833-6.

75. Javaheri S, Ahmed M, Parker TJ, Brown CR. Effects of nasal $\mathrm{O}_{2}$ on sleep-related disordered breathing in ambulatory patients with stable heart failure. Sleep. 1999;22(8):1101-6.

76. Javaheri S, Parker TJ, Wexler L, Liming JD, Lindower P, Roselle GA. Effect of theophylline on sleep-disordered breathing in heart failure. N Engl J Med. 1996;335(8):562-7. doi:10.1056/NEJM199608223350805

77. Javaheri S. Acetazolamide improves central sleep apnea in heart failure: a double-blind, prospective study. Am J Respir Crit Care Med. 2006;173(2):234-7. doi:10.1164/rccm.200507-1035OC
78. Naughton MT, Liu PP, Bernard DC, Goldstein RS, Bradley TD. Treatment of congestive heart failure and Cheyne-Stokes respiration during sleep by continuous positive airway pressure. Am J Respir Crit Care Med. 1995;151(1):92-7. doi:10.1164/ajrccm.151.1.7812579

79. Sin DD, Logan AG, Fitzgerald FS, Liu PP, Bradley TD. Effects of continuous positive airway pressure on cardiovascular outcomes in heart failure patients with and without CheyneStokes respiration. Circulation. 2000;102(1):61-6.

doi:10.1161/01.CIR.102.1.61

80. Bradley TD, Logan AG, Kimoff RJ, Sériès F, Morrison D, Ferguson $\mathrm{K}$, et al. CANPAP Investigators. Continuous positive airway pressure for central sleep apnea and heart failure. $\mathrm{N}$ Engl J Med. 2005;353(19):2025-33. doi:10.1056/NEJMoa051001

81. Woodring JH. Pulmonary artery-bronchus ratios in patients with normal lungs, pulmonary vascular plethora, and congestive heart failure. Radiology. 1991;179(1):115-22. doi:10.1148/radiology.179.1.2006261

82. Scott MC, Winters ME. Congestive heart failure. Emerg Med Clin North Am. 2015;33(3):553-62. doi:10.1016/j.emc.2015.04.006

83. Cardinale L, Massimiliano Priola A, Moretti F, Volpicelli G. Effectiveness of chest radiography, lung ultrasound and thoracic computed tomography in the diagnosis of congestive heart failure. World J Radiol. 2014;28(6):230-7. doi:10.4329/wjr.v6.i6.230

84. Cardinale L, Volpicelli G, Lamorte A, Martino J, Veltri A. Revisiting signs, strengths and weaknesses of standard chest radiography in patients with acute dyspnea in the emergency department. J Thorac Dis. 2012 Aug;4(4):398-407.

Sažetak

\section{SRČANO-PLUĆNE INTERAKCIJE S POSLJEDIČNIM PLUĆNIM ABNORMALNOSTIMA U BOLESNIKA S KRONIČNIM SRČANIM ZATAJENJEM}

\section{Alerić, D. Katalinić i M. Krpan}

Kronično srčano zatajenje značajno opterećuje bolesnika i njegovu obitelj kao i zdravstveni sustav u cjelini budući da je odgovorno za velik broj hospitalizacija. Unatoč golemim naporima u liječenju većine srčanih poremećaja iznimka ostaje klinički sindrom kroničnog srčanog zatajenja učestalost kojega raste s neznatnim uspjehom produženja ukupnog preživljenja bolesnika. Kronično srčano zatajenje je povezano s visokom stopom pobola te nepovoljnom prognozom, čak lošijom uspoređujući sa stopom preživljenja za neke vrste zloćudnih tumora. Razlog porasta učestalosti kroničnog srčanog zatajenja u razvijenim zemljama je produljenje ljudskog vijeka zahvaljujući mjerama suvremenog farmakološkog i intenzivnog liječenja, boljoj sekundarnoj profilaksi i starenju populacije. Kronična plućna bolest je česta pojava u bolesnika s kroničnim srčanim zatajenjem. Oba stanja predstavljaju dijagnostički i terapijski izazov budući da dijele pojedine zajedničke čimbenike rizika i patofiziološke mehanizme nastanka. Cilj ovoga rada je ispitati različite mehanizme odgovorne za simptome kroničnog srčanog zatajenja s posljedičnim plućnim interakcijama i abnormalnostima plućne funkcije.

Ključne riječi: Srčano zatajivanje; Srčane bolesti; Plućne bolesti 